\title{
On Enterprise Pre-Tax Deduction Ways for Charitable Donations
}

\author{
Kexin Zheng \& Juan Zhang \\ School of Economics and Management, Changchun University of Science and Technology \\ Changchun 130022, China \\ E-mail: zhengkexin830@163.com
}

\begin{abstract}
The Law of the People's Republic of China on Enterprise Income Tax regulates that in relation to the expenses from charitable donations incurred by Enterprises, the portion within $12 \%$ of the total annual profit may be deducted from the taxable income. The application of this Article is helpful for simplifying the calculation of enterprise income tax and encouraging tax-payers to engage in charitable donations. However, there is some problems and defects in practice. In this paper, by means of comparative analyses, authors explore the contradiction between the calculation of deduction limits for donations based on total annual profits and the principle of enterprise income tax calculation, together with the absence of rationality in operation, and further argue some new thoughts for improving the pre-tax deduction of charitable donations.
\end{abstract}

Keywords: Total annual profits, Taxable income, Charitable donations

The Law of the People's Republic of China on Enterprise Income Tax regulates: in relation to the expenses from charitable donations incurred by Enterprises, the portion within $12 \%$ of the total annual profit may be deducted from the taxable income. Here, the total annual profits mean the annual accounting profits in accordance with the provisions in National General Accounting System.

Compared with former Interim Regulations on Enterprise Income Tax, the new tax law concerns two changes in enterprise pre-tax deduction for charitable donations.

Firstly, the tax base of calculating pre-tax deduction for charitable donations changes from taxable income to total annual profits. The former regulations that take taxable income as tax base are confronted with disagreement in understanding and contradiction in operation, in calculating the deduction limits donations. Taking total annual profits as the tax base can get rid of defects, making policies more operational.

Secondly, the deduction ratio rises from $3 \%$ to $12 \%$. The rise of ratio, on one hand, reduces the tax burden of expenses from charitable donations incurred by enterprise, which can positively motivate enterprise's enthusiasm for charitable donations. On the other hand, the rise of ratio reflects the progress of tax law of China in meeting international standards.

However, in practicing the new Article of the charitable donation deduction, some contradictions and problems wait for resolutions in taking total annual profits as the tax base.

First of all, taking total annual profits as the tax base for calculating the pre-tax deduction of charitable donations violates the calculation principles of enterprise income tax.

Total annual profits and taxable income are two different concepts. Total profits, as an accounting concept, represent enterprise's financial fruits in production and operation during certain period in accordance with the provisions of financial accounting system. Taxable income, as a tax concept, is the tax base in accordance with the provisions in enterprise income tax law. Due to different calculations, the two have differences, namely tax adjustments. Use the limits calculated by total annual profits offset taxable income, which violates the relevance principle of calculating the deduction of enterprise income tax. The differences will inevitably affect the rationality of pre-tax deduction for charitable donations. For example:

Case 1: Enterprise A, total annual profits in 2009: 10 million Yuan, including 2 million Yuan as charitable donations. Suppose no other tax adjustments. According to provisions of The Law of the People's Republic of China on Enterprise Income Tax, the pre-tax deduction limits for charitable donations are 1.2 million Yuan $\left(10^{*} 12 \%\right)$, but the real charitable donations are 2 million Yuan, larger than the deduction limits. So, the legal 
pre-tax deduction is 1.2 million Yuan. The charitable donations produce 0.8 million Yuan (2-1.2) as tax adjusted increment. Then, the taxable income of enterprise A is 10.8 million Yuan $(10+0.8)$, and the payable tax is 2.7 million Yuan $(10.8 * 25 \%)$.

Case 2: Enterprise B, total annual profits in 2009: 15 million Yuan, including 5 million Yuan income from interests on government bonds, and 2 million Yuan charitable donations. Suppose no other tax adjustments. According to provisions of The Law of the People's Republic of China on Enterprise Income Tax, the pre-tax deduction limits for charitable donations are 1.8 million Yuan $(15 * 12 \%)$, but the real charitable donations are 2 million Yuan, larger than the deduction limits. So, the legal pre-tax deduction is 1.8 million Yuan. The charitable donations produce 0.2 million Yuan (2-1.8) as tax adjusted increment. Meanwhile, interests on government bonds are exempted from tax. It produces 5 million Yuan tax adjusted decrement. Therefore, the taxable income of enterprise B is 10.2 million Yuan (15+0.2-5), and the payable tax is 2.55 million Yuan $(10.2 * 25 \%)$.

The two cases above illustrate: as an enterprise has tax adjusted decrements (such as income from interests on government bonds, tax-exempted income, etc.), total annual profits are larger than taxable income. And the pre-tax deduction for charitable donations increase, which reduces the enterprise's tax burden but cause economic losses for the country. In contrast, as an enterprise has tax adjusted increments (such as administrative fines, expenses for sponsoring, etc.), total annual profits are smaller than taxable income. And the pre-tax deduction for charitable donations decline, which increases the enterprise's tax burden, causing economic losses. As a matter of fact, pre-tax deduction for charitable donations is a kind of preferential tax treatment, and the deduction reduces the taxable income in current period. If income from interests on government bonds, administrative fines, and other non-tax elements are included in the tax base for calculating the limits, it will obviously contradict the calculation principles of enterprise income tax.

Secondly, in establishing the deduction limits for donations, the practical donations should not be included in the calculation base.

If take donations as parts of calculation base (total annual profits), it will result in: the more the donations, the smaller the calculation base is, then the smaller the calculated pre-tax deduction limits are. That is a contradiction. Cases for illustration:

Case 3: Enterprise A, annual operating profits in 2009 are 10 million Yuan, not any non-operating income or expenses, its total annual profits are 10 million Yuan. Suppose no tax adjustments. Then, the taxable income of the enterprise is 10 million Yuan, and the income tax is 2.5 million Yuan (10*25\%).

Case 4: Enterprise B, total operating profits in 2009 are 10 million Yuan, not any non-operating income, with one non-operating expense ------ 1 million Yuan charitable donations, and its total annual profits are 9 million Yuan (10-1). According to provisions of The Law of the People's Republic of China on Enterprise Income Tax, the pre-tax deduction limits for charitable donations are 1.08 million Yuan $(900 * 12 \%)$, and the real charitable donations are 1 million Yuan, smaller than the deduction limits, no necessary for tax adjustment. The 1 million Yuan charitable donations can be deducted practically. Suppose no other tax adjustments. The taxable income of the enterprise is 9 million Yuan in 2009, and the income tax is 2.25 million Yuan $(9 * 25 \%)$.

Case 5: Enterprise C, total operating profits in 2009 are 10 million Yuan, not any non-operating income, with one non-operating expense ------ 3 million Yuan charitable donations, and its total annual profits are 7 million Yuan (10-3). According to provisions of The Law of the People's Republic of China on Enterprise Income Tax, the pre-tax deduction limits for charitable donations are 0.84 million Yuan $(700 * 12 \%)$, and the real charitable donations are 3 million Yuan, larger than the deduction limits. So the practical pre-tax deduction should be 0.84 million Yuan. The charitable donations produce 2.16 million Yuan (3-0.84) as tax adjusted increment. Suppose no other tax adjustments. The taxable income of the enterprise is 9.16 million Yuan $(7+2.16)$ in 2009, and the income tax is 2.29 million Yuan $(9.16 * 25 \%)$.

From the cases above, as the charitable donations are under the deduction limits (within 12\% of total annual profits) according to provisions of The Law of the People's Republic of China on Enterprise Income Tax, payable tax in current period will be reduced in accordance with the enterprise income ratio. Compare Case 3 and 4. Under the same conditions, enterprise B, who has 1 million Yuan charitable donations, pays taxes 0.25 million Yuan (2.5-2.25) taxes less than enterprise A, who has no charitable donations, pays. However, as the charitable donations of enterprise exceed the deduction limits (within 12\% of total annual profits) according to provisions of The Law of the People's Republic of China on Enterprise Income Tax, the enterprise will pay more income taxes due to the rise of charitable donations. In Case 5, under the same conditions, enterprise $\mathrm{C}$, who has 3 million charitable donations, surpassing the deduction limits, pays taxes 0.04 million Yuan (2.29-2.25) more than enterprise B pays. For further explaining the tendency of changes, suppose enterprise C in 2009 has 10 million 
Yuan charitable donations (be equal to annual operating profits in current period), then the total annual profits of the enterprise is 0 (10-10). According to provisions of The Law of the People's Republic of China on Enterprise Income Tax, the pre-tax deduction limits are $0(0 * 12 \%)$. Then, the charitable donations produce 10 million Yuan tax adjusted increments (real charitable donations 10 million Yuan - pre-tax deduction limits 0). So, the taxable income of the enterprise in 2009 is 10 million Yuan $(0+1000)$, and the income tax is 2.5 million Yuan $(10 * 25 \%)$. Compared with Case 3, it is easy to know that the enterprise gets nothing from the charitable donations.

The explanation above shows that the pre-tax deduction will rise along with the rise of charitable donations as the charitable donations are under the deduction limits, which results in the decrease of payable taxes in current period; and the pre-tax deduction will decline along with the rise of charitable donations as the charitable donations are beyond the deduction limits, which results in the rise of payable taxes in current period. That is in accordance with the purpose of national tax laws. However, as charitable donations are beyond the deduction limits, the more the charitable donations, the less the pre-tax deduction is, and the more the payable taxes are. That obviously violates the original intention of the state encouraging enterprises to engage in charitable donations.

To sum up, it is not completely reasonable to take total annual profits as the calculation base for enterprise's pre-tax deduction for charitable donations. In comparison, to take taxable income as the base, adopted by the former tax laws, is more proper for the calculation of pre-tax deduction. However, because of the second contradiction mentioned above, that is, the practical donations and the pre-tax deduction change reversely, we suggest to taking references from the calculation of deduction limits for individual charitable donations, that is, in establishing the calculation base (namely taxable income), the first step is not to deduct the practical charitable donations, but compare the deduction limits calculated by the calculation base (the taxable income before deducting charitable donations) with the practical donations, then choose the smaller and deduct the smaller from taxable income.

Use the "taxable income before deducting charitable donations" as the calculation base to compare Case 1 and 2 . In Case 1, there are no other tax adjustments except for charitable donations. So, the "taxable income before deducting charitable donations" is 12 million Yuan $(10+2)$, and the pre-tax deduction for charitable donations is 1.44 million Yuan $(12 * 12 \%)$, smaller than the real charitable donations 2 million Yuan. The practical pre-tax deduction will be 1.44 million Yuan. Then, the taxable income of enterprise A is 10.56 million Yuan (12-1.44), and the payable income tax is 2.64 million Yuan $(10.56 * 25 \%)$. In Case 2, except for charitable donations, there is another tax adjustment ------ income from interests on government bonds. The taxable income will be reduced. Therefore, the "taxable income before deducting charitable donations" is 12 million Yuan $(15-5+2)$, and the pre-tax deduction limits for charitable donations are 1.44 million Yuan $(12 * 12 \%)$, smaller than the real charitable donations 2 million Yuan. The pre-tax deduction should be 1.44 million Yuan. Then, the taxable income of enterprise B is 10.56 million Yuan (12-1.44) in current period, and the payable income taxes are 2.64 million Yuan $(10.56 * 25 \%)$. After necessary calculations, we know that: as we take the "taxable income before deducting charitable donations" as the calculation base to calculate the pre-tax deduction limits for charitable donations, the results are exempted from the influences of income from interests on government bonds and other non-tax elements, making it more practical for calculating the pre-tax deduction.

Calculate the Case 3, 4, and 5 by new ways and take the "taxable income before deducting charitable donations" as the calculation base. Because there is not any tax adjustment in Case 3, the results do not change. In Case 4, there is only one tax adjustment that concerns the 1 million Yuan charitable donations. So, the "taxable income before deducting charitable donations" is 10 million Yuan $(9+1)$, and the pre-tax deduction for charitable donations is 1.2 million Yuan $\left(10^{*} 12 \%\right)$, larger than the real charitable donation 1 million Yuan. Then, the real pre-tax deduction should be 1 million Yuan. So, the taxable income of enterprise B is 9 million Yuan (10-1) in current period, and the payable income taxes are 2.25 million Yuan $(9 * 25 \%)$. Similar to Case 4, Case 5 merely concerns one tax adjustment that is the 3 million Yuan charitable donations. So, the "taxable income before deducting charitable donations" is 10 million Yuan $(7+3)$, and the pre-tax deduction for charitable donations is 1.2 million Yuan $\left(10^{*} 12 \%\right)$, smaller than the real charitable donations 3 million Yuan. Then, the real pre-tax deduction should be 3 million Yuan. So, the taxable income of enterprise C is 8.8 million Yuan (10-1.2) in current period, and the payable income taxes are 2.2 million Yuan $(8.8 * 25 \%)$. The analyses above show that: if we take the "taxable income before deducting charitable donations" as the calculation base, with same other conditions, the enterprise's taxable income and payable income taxes decline along with the rise of charitable donations. Till charitable donations reach the pre-tax deduction limits, the payable income taxes stop declining and keep the same.

To sum up, as we take the "taxable income before deducting charitable donations" as the calculation base to 
calculate the pre-tax deduction limits for charitable donations, on one hand, it excludes all influences from non-taxable items on the calculation of deduction limits, more exactly reflecting the fundamental principle of enterprise income pre-tax deduction. On the other hand, it gets rid of the contradiction caused by the reverse changes of real charitable donations and pre-tax deduction limits as absorbing real charitable donations into tax calculation base, further reflecting the rationality of preferential tax treatments of the state, and insuring the positive effects of preferential tax treatments.

\section{References}

Notices for The Pre-tax Deduction of Charitable Donations. Finance \& Tax [2008] No.160.

Regulations for The Law of the People's Republic of China on Enterprise Income Tax. State Council [2007] No.512.

The Law of the People's Republic of China on Enterprise Income Tax. Order of the President [2007] No.63.

Welfare Donations Law of the People's Republic of China. Order of the President [1999] No.19. 